\title{
PERLINDUNGAN HUKUM TERHADAP HAK TERKAIT PRODUSER FONOGRAM ATAS MECHANICAL RIGHTS FONOGRAM YANG DIKOMERSILKAN OLEH PIHAK LAIN
}

\author{
Usak \\ Dosen Program Studi Ilmu Hukum Universitas Halmahera \\ Korespondensi: usakhalmahera@yahoo.com
}

\begin{abstract}
Abstrak
Tujuan penelitian ini adalah untuk mengkaji perlindungan hukum terhadap hak terkait produser fonogram atas mechanical rights fonogram yang dikomersilkan oleh pihak lain dalam ranah Hukum Hak Cipta di Indonesia. Isu hukum yang sering terjadi adalah mechanical rights milik produser fonogram sering dilanggar oleh pihak lain yang bukan pemegang mechanical rights atau tidak mendapatkan ijin secara langsung dari pemegang mechanical rights. Penelitian ini menggunakan metode penelitian hukum. Mechanical rights fonogram terkait dengan penggandaan atau reproduksi fonogram. Produser fonogram mempunyai hak eksklusif untuk memberi ijin reproduksi langsung atau tidak langsung fonogramnya, dengan berbagai cara atau bentuk. Mechanical rights identik dengan "Hak Terkait” yang merupakan hak eksklusif produser fonogram. Undang-Undang Hak Cipta di Indonesia mampu memberikan perlindungan hukum terhadap hak terkait produser fonogram atas mechanical rights fonogram yang dikomersilkan oleh pihak lain.
\end{abstract}

Kata-kata Kunci: Mechanical Rights, Fonogram, Produser Fonogram.

\begin{abstract}
The purpose of this study was about to examine the legal protection of neighboring rights producers of phonograms on phonograms of mechanical rights which commercialized by other parties in the realm of copyright law in Indonesia. Legal issues that often occurs is mechanical rights belong producers of phonograms often violated by others who are not holders of mechanical rights or do not get permission directly from the holders of mechanical rights. This study uses legal research. Mechanical rights on phonograms relating to procurement or reproduction of a phonogram. Producers of phonograms shall enjoy the exclusive right of authorizing the direct or indirect reproduction of their phonograms, in any manner or form. Mechanical rights on phonograms synonymous with "Neighboring Rights" is an exclusive right of producers of phonograms. Copyright Law in Indonesia able to provide legal protection of neighboring rights producers of phonograms on phonograms of mechanical rights which commercialized by other parties.
\end{abstract}

Key Words: Mechanical Rights, Phonograms, Producers of Phonograms. 


\section{PENDAHULUAN}

Penelitian ini hendak membahas perlindungan hukum terhadap hak terkait produser fonogram atas mechanical rights fonogram yang dikomersilkan oleh pihak lain berdasarkan Undang-Undang Nomor. 28 Tahun 2014 (UU No. 28 Tahun 2014). Isu hukum yang sering terjadi adalah mechanical rights produser fonogram sering dilanggar oleh banyak pihak yang bukan pemegang hak terkait dari hak cipta atau tidak mendapatkan izin secara langsung dari pemegang hak terkait. Seperti contoh kasus yang terjadi pada tahun 2008 yaitu Djoni Tan, pengusaha ring tone yang divonis 4 (empat) tahun penjara dan denda Rp 3.000 .000 (Tiga juta rupiah) oleh Pengadilan Negeri Jakarta Pusat meskipun sudah mengantongi perjanjian lisensi dan sertifikat dari Yayasan Karya Cipta Indonesia (YKCI). Hakim berpendapat, dalam praktiknya, YKCI hanya berhak memberikan lisensi atas hak mengumumkan (performing right) - bukan hak untuk memperbanyak atau menggandakan (mechanical right). ${ }^{1}$ Contoh kasus lain yang terjadi yaitu kasus pelanggaran mechanical rights yang dilaporkan pihak rumah produksi musik Nagaswara pada sejumlah rumah karaoke. ${ }^{2}$
Hak Cipta merupakan hak eksklusif yang terdiri atas hak moral dan hak ekonomi. ${ }^{3}$ Berdasarkan hal tersebut, maka hak ekonomi (economic rights) dari pemegang hak cipta ini tentunya tidak dapat dikesampingkan. Hak ekonomi merupakan hak eksklusif pencipta atau pemegang hak cipta untuk mendapatkan manfaat ekonomi atas ciptaan. ${ }^{4}$ Hak ekonomi pada lagu terdiri dari dua hak, yaitu hak untuk pengumuman lagu (performing rights) dan hak untuk menggandakan lagu (mechanical rights).

Mechanical rights merupakan hak eksklusif pemegang Hak Cipta yang diberikan kepada label rekaman untuk melakukan penggandaan mekanikal komposisi musik, lagu, atau album rekaman yang nantinya akan dikomersilkan. ${ }^{5}$ UU No. 28 Tahun 2014 telah menggantikan UU No. 19 Tahun 2002 tentang Hak Cipta. Dalam UU No. 28 Tahun 2014 diatur lebih detail mengenai Hak Terkait yaitu hak yang berkaitan dengan Hak Cipta yang merupakan hak eksklusif bagi pelaku pertunjukan, produser fonogram, atau lembaga Penyiaran - salah satunya adalah mechanical rights.

Melalui penelitian ini, penulis hendak berargumen bahwa hukum harus dapat memberikan perlindungan

Anonim, 'Lantaran Memperjualbelikan Lagu Tanpa Izin', (Selasa, 03 Juni 2008), <http:// www.hukumonline.com/berita/baca/hol19397/lantaran-memperjualbelikan-lagu-tanpa-izin>, diakses 12 April 2015.

2 Anonim, 'Nagaswara Bakal Somasi 13 Rumah Karaoke Soal Hak Cipta', 103 September2014),<http://hot.detik.com/music/read/2014/09/03/161025/2680323/228/>, diakses 12 April 2015.

$3 \quad$ Lihat Pasal 4 UU No. 28 Tahun 2014.

$4 \quad$ Lihat Pasal 8 UU No. 28 Tahun 2014.

$5 \quad$ Wendi Putranto, Manual Cerdas Menguasai Bisnis Musik (Bentang Pustaka 2009) 79. 
bagi ciptaan pencipta dan pemegang hak cipta sehingga mampu mengembangkan daya kreasi masyarakat yang pada akhirnya bermuara pada tujuan berhasilnya perlindungan Hak Cipta. Beberapa studi ekonomi yang dilakukan di negara-negara maju membuktikan produk yang dilindungi dengan Hak Kekayaan Intelektual mampu meningkatkan pendapatan nasional suatu negara serta menambah angka angkatan kerja nasional. ${ }^{6}$

Sesuai dengan isu hukum yang ditujukan untuk mengkaji perlindungan hukum terhadap hak terkait produser fonogram atas mechanical rights fonogram yang dikomersilkan oleh pihak lain dalam ranah hukum Hak Cipta, maka metode penelitian yang digunakan dalam penelitian ini adalah penelitian hukum normatif melalui pendekatan konseptual. Penelitian hukum normatif adalah suatu proses untuk menemukan aturan hukum, prinsip-prinsip hukum, maupun doktrin-doktrin hukum guna menjawab isu hukum yang dihadapi. ${ }^{7}$ Pendekatan konseptual dilakukan manakala peneliti tidak beranjak dari aturan hukum yang ada. ${ }^{8}$

\section{PEMBAHASAN}

\section{Hak Terkait Atas Mechanical Rights Fonogram}

Hak Terkait adalah hak yang berkaitan dengan Hak Cipta yang merupakan hak eksklusif bagi pelaku pertunjukan, produser fonogram, atau lembaga penyiaran. ${ }^{9}$ Sedangkan Mechanical right berkenaan dengan penggandaan atau reproduksi suatu ciptaan. Hak ini disebut mechanical right karena berkaitan dengan teknologi mesin yang dapat menggandakan ciptaan. Penggandaan adalah proses, perbuatan, atau cara menggandakan satu salinan ciptaan dan/atau fonogram atau lebih dengan cara dan dalam bentuk apapun, secara permanen atau sementara. ${ }^{10}$ Fonogram adalah fiksasi suara pertunjukan atau suara lainnya, atau representasi suara, yang tidak termasuk bentuk fiksasi yang tergabung dalam sinematografi atau ciptaan audiovisual lainnya. ${ }^{11}$ Fiksasi adalah perekaman suara yang dapat didengar, perekaman gambar atau keduanya, yang dapat dilihat, didengar, digandakan, atau dikomunikasikan melalui perangkat apapun. ${ }^{12}$

6 Eddy Damian, Hukum Hak Cipta Menurut Beberapa Konvensi Internasional, Undang-Undang Hak Cipta 1997 dan Perlindungan Terhadap Buku serta Perjanjian Penerbitannya (Citra Aditya Bakti 1997) 2.

$7 \quad$ Peter Mahmud Marzuki, Penelitian Hukum (Kencana Prenada Media Group 2010) 35.

$8 \quad$ Ibid., 137.

$9 \quad$ Lihat Pasal 1 angka 5 UU No. 28 Tahun 2014.

10 Lihat Pasal 1 angka 12 UU No. 28 Tahun 2014.

11 Lihat Pasal 1 angka 14 UU No.28 Tahun 2014.

12 Lihat Pasal 1 angka 13 UU No. 28 Tahun 2014. 
Mechanical rights merupakan hak eksklusif pemegang Hak Cipta yang diberikan kepada label rekaman untuk melakukan penggandaan mekanikal komposisi musik, lagu, atau album rekaman yang nantinya akan dikomersilkan. ${ }^{13}$ Siapa saja yang ingin merekam, memperbanyak, serta mengedarkan sebuah karya cipta bagi kepentingan komersial berkewajiban mendapatkan lisensi mekanikal. ${ }^{14} \mathrm{UU}$ No. 28 Tahun 2014 menyebutnya sebagai Produser Fonogram yaitu orang atau badan hukum yang pertama kali merekam dan memiliki tanggung jawab untuk melaksanakan perekaman suara atau perekaman bunyi, baik perekaman pertunjukan maupun perekaman suara atau bunyi lain (vide Pasal 1 angka 7 UU No. 28 Tahun 2014). Bentuk-Bentuk Mechanical Rights yaitu: ${ }^{15}$

1. Hak Perbanyakan (menggandakan) Perbanyakan adalah penambahan jumlah suatu ciptaan baik secara keseluruhan maupun bagian yang sangat substansial dengan menggunakan bahan-bahan yang sama ataupun tidak sama, termasuk pengalihwujudan secara permanen atau temporer.

2. Hak mengalihwujudkan

Pengalihwujudan adalah pengubahan bentuk. Mengubah karya musik dari format CD (Compact Disc) menjadi MP3 (MPEG 1 layer 3), Winamp dan Windows Media Player dengan kualitas yang sama baiknya dengan karya musik aslinya.

Menurut ASCAP (the American Society of Composers, Authors and Publishers):

"The mechanical right is the right granted by a copyright owner of a musical work to an entity like a record label, allowing that musical work to be reproduced in a sound recording (such as a CD or, increasingly, a digital format like MP3). ${ }^{16}$

Lisensi Mekanikal diberikan kepada produser fonogram sebagai bentuk ijin penggunaan karya cipta. Hal tersebut juga dinyatakan oleh Mihaly Ficsor bahwa:

The expression "mechanical rights" is generally understood to mean the rights to authorize the reproduction of works in the form of recordings (phonograms or audiovisual fixations) produced "mechanically" in the widest sense of the word, including electro-acoustic and electronic procedures. The most typical and economically most important "mechanical right" is the right of composers of musical works - and authors of accompanying words - to authorize the sound recording of such works. ${ }^{17}$

Hak ekonomi atas karya fonogram menjadi milik produser fonogram, disebut sebagai Master Rekaman (Sound

13 Wendi Putranto, Op.cit., 79.

14 Husain Audah, Hak Cipta \& Karya Cipta Musik (Pustaka Litera Antar Nusa 2004) 19.

15 Hulman Panjaitan dan Wetmen Sinaga, Performing Right Hak Cipta atas Karya Musik dan Lagu Serta Aspek Hukumnya (Ind Hill Co, 2011) 77.

16 ASCAP, A Bill of Rights For Songwriters And Composers (Music Copyright in the Digital Age: A Position Paper, Maret 2008) 7.

17 Mihaly Ficsor, Collective Management of Copyright And Related Rights (Geneva: World Intellectual Property Organization (WIPO) 2002) 49. 
Recording), dan hak tersebut merupakan mechanical rights yang identik dengan hak cipta, yaitu, "Neighboring Rights" atau "Hak Terkait"18, yang diatur dalam Pasal 24 UU No. 28 Tahun 2014. Royalti atas mechanical right yang diterima dibayarkan oleh pihak yang mereproduksi atau merekam langsung kepada pemegang hak terkait (biasanya perusahaan penerbit musik (publisher) yang mewakili komposer/pencipta lagu). ${ }^{19}$

Jaminan Perlindungan Terhadap Hak Terkait Dalam Hukum Nasional dan Hukum Internasional

Dasar perlindungan nasional secara konstitusional terkait Hak Cipta tercantum dalam Pasal 28C UUD NRI Tahun 1945:

(1) Setiap orang berhak mengembangkan diri melalui pemenuhan kebutuhan dasarnya, berhak mendapat pendidikan dan memperoleh manfaat dari ilmu pengetahuan dan teknologi, seni dan budaya, demi meningkatkan kualitas hidupnya dan demi kesejahteraan umat manusia.

(2) Setiap orang berhak untuk memajukan dirinya dalam memperjuangkan haknya secara kolektif untuk membangun masyarakat, bangsa dan negaranya.
Dalam lingkup hukum nasional, UU No. 28 Tahun 2014 mengatur perlindungan terhadap hak yang masih terkait erat dengan hak cipta, yaitu hak terkait (neighboring rights). Hak Terkait tidak akan timbul bila tidak ada izin dari pencipta asli untuk menggunakan ciptaannya. Dalam UU No. 28 Tahun 2014 juga diatur lebih detail mengenai Hak Cipta yang merupakan hak eksklusif yang terdiri atas hak moral dan hak ekonomi dan juga mengenai Hak Terkait yaitu hak yang berkaitan dengan Hak Cipta yang merupakan hak eksklusif bagi pelaku pertunjukan, produser fonogram, atau lembaga Penyiaran.

Jaminan perlindungan terhadap Hak Terkait tersirat dalam Pasal 2 UU No. 28 Tahun 2014 yang menyatakan bahwa:

Undang-Undang ini berlaku terhadap:

a. semua Ciptaan dan produk Hak Terkait warga negara, penduduk, dan badan hukum Indonesia;

b. semua Ciptaan dan produk Hak Terkait bukan warga negara Indonesia, bukan penduduk Indonesia, dan bukan badan hukum Indonesia yang untuk pertama kali dilakukan Pengumuman di Indonesia;

c. semua Ciptaan dan/atau produk Hak Terkait dan pengguna Ciptaan dan/atau produk Hak Terkait bukan

18 Rezky Lendi Maramis, 'Perlindungan Hukum Hak Cipta Atas Karya Musik Dan Lagu Dalam Hubungan Dengan Pembayaran Royalti' (2014) 2 Jurnal Lex Privatum 116, 112.

19 Lucky Setiawati, 'Hak Cipta Dalam Industri Musik', <http://www.hukumonline.com/klinik/ detail/lt506ec90e47d25/apakah-menyanyikan-ulang-lagu-orang-lain-melanggar-hak-cipta>, diakses 10 April 2015. 
warga negara Indonesia, bukan penduduk Indonesia, dan bukan badan hukum Indonesia dengan ketentuan:

1. negaranya mempunyai perjanjian bilateral dengan negara Republik Indonesia mengenai pelindungan Hak Cipta dan Hak Terkait; atau

2. negaranya dan negara Republik Indonesia merupakan pihak atau peserta dalam perjanjian multilateral yang sama mengenai pelindungan Hak Cipta dan Hak Terkait.

Dalam rangka jaminan perlindungan di tingkat Internasional, Indonesia telah ikut serta menjadi anggota dalam Persetujuan Pembentukan Organisasi Perdagangan Dunia (Agreement Establishing the World Trade Organization) yang mencakup Persetujuan tentang Aspek-Aspek Dagang Hak Kekayaan Intelektual (Trade Related Aspects of Intellectual Property Rights), melalui UU No. 7 Tahun 1994. Selain itu, Indonesia telah meratifikasi Berne Convention for the Protection of Artistic and Literary Works melalui Keputusan Presiden No. 18 Tahun 1997 dan World Intellectual Property Organization Copyright Treaty melalui Keputusan Presiden No. 19 Tahun 1997, serta World Intellectual Property Organization Performances and Phonograms Treaty melalui Keputusan Presiden No. 74 Tahun 2004.

Jaminan perlindungan terhadap Hak Terkait diakui secara internasional di Roma pada tahun 1961 dengan dibentuk suatu konvensi khusus yang mengatur perlindungan terhadap hak terkait, yaitu International Convention Protection for Performers, Producers of Phonograms and Broadcasting Organizations, di mana Artikel 5 ayat 1 dan 2 serta Artikel 10 menyatakan bahwa:

Article 5

1. Each Contracting State shall grant national treatment to producers of phonograms if any of the following conditions is met:

(a) the producer of the phonogram is a national of another Contracting State (criterion of nationality);

(b) the first fixation of the sound was made in another Contracting State (criterion of fixation);

(c) the phonogram was first published in another Contracting State (criterion of publication).

2. If a phonogram was first published in a non-contracting State but if it was also published, within thirty days of its first publication, in a Contracting State (simultaneous publication), it shall be considered as first published in the Contracting State.

Article 10

Producers of phonograms shall enjoy the right to authorize or prohibit the direct or indirect reproduction of their phonograms. 
Rome Convention for the Protection of Performers, Producers of Phonograms and Broadcasting Organizations 1961 memiliki keterkaitan dengan WIPO Performances and Phonograms Treaty 1996 yang telah diratifikasi melalui Keputusan Presiden Republik Indonesia No. 74 Tahun 2004. Dalam Artikel 1 ayat 1 WIPO Performances and Phonograms Treaty 1996 disebutkan bahwa:

Nothing in this Treaty shall derogate from existing obligations that Contracting Parties have to each other under the International Convention for the Protection of Performers, Producers of Phonograms and Broadcasting Organizations done in Rome, October 26, 1961 (hereinafter the 'Rome Convention').

Artikel 11, Artikel 12 ayat 1, Artikel 13 ayat 1 dan Artikel 14 WIPO Performances and Phonograms Treaty 1996 memberikan jaminan perlindungan terhadap mechanical right atau penggandaan fonogram yang menjadi milik produser fonogram:

\section{Article 11}

Producers of phonograms shall enjoy the exclusive right of authorizing the direct or indirect reproduction of their phonograms, in any manner or form.

\section{Article 12}

Producers of phonograms shall enjoy the exclusive right of authorizing the making available to the public of the original and copies of their phonograms through sale or other transfer of ownership.

\section{Article 13}

Producers of phonograms shall enjoy the exclusive right of authorizing the commercial rental to the public of the original and copies of their phonograms, even after distribution of them, by or pursuant to, authorization by the producer.

\section{Article 14}

Producers of phonograms shall enjoy the exclusive right of authorizing the making available to the public of their phonograms, by wire or wireless means, in such a way that members of the public may access them from a place and at a time individually chosen by them.

Berdasarkan paparan sebelumnya, maka perlindungan hukum terhadap hak terkait produser fonogram atas mechanical rights fonogram dalam tataran hukum nasional telah dijamin oleh UU No. 28 Tahun 2014. Sedangkan dalam tataran hukum internasional telah dijamin oleh Rome Convention for the Protection of Performers, Producers of Phonograms and Broadcasting Organizations 1961 dan WIPO Performances and Phonograms Treaty 1996 yang telah diratifikasi melalui Keputusan Presiden Republik Indonesia No. 74 Tahun 2004.

\section{Analisis Perlindungan Hukum Hak Terkait Produser Fonogram atas Mechanical Rights Fonogram yang Dikomersilkan Oleh Pihak Lain dalam UU No. 28 Tahun 2014}

Perlindungan hukum mempunyai makna sebagai perlindungan dengan menggunakan sarana hukum atau perlindungan yang diberikan oleh hukum, ditujukan kepada perlindungan terhadap kepentingan-kepentingan 
tertentu, yaitu dengan cara menjadikan kepentingan yang perlu dilindungi tersebut ke dalam sebuah hak hukum. ${ }^{20}$ Berdasarkan analisis peneliti, UU No. 28 Tahun 2014 telah memberikan perlindungan hukum terhadap hak terkait produser fonogram atas mechanical rights fonogram yang dikomersilkan oleh pihak lain dalam ranah hukum Hak Cipta di Indonesia melalui pengaturan perlindungan sebagai berikut:

\section{Perlindungan Terhadap Produser Fonogram sebagai Subjek Pemegang Hak}

Apabila terjadi penggandaan atau perbanyakan karya fonogram oleh pihak lain, maka perlindungannya ada pada subyeknya yaitu produser fonogram karena ia telah memprakarsai kegiatan merekam lagu-lagu dengan melibatkan penyanyi, musisi dan pencipta lagu. Mechanical rights merupakan sesuatu yang terkait dengan hak cipta, yaitu, "Neighboring Rights" atau "Hak Terkait", yang perlindungannya diatur dalam Pasal 24 UU No. 28 Tahun 2014:

(1) Produser Fonogram memiliki hak ekonomi.

(2) Hak ekonomi Produser Fonogram sebagaimana dimaksud pada ayat (1) meliputi hak melaksanakan sendiri, memberikan izin, atau melarang pihak lain untuk melakukan: a. penggandaan atas Fonogram dengan cara atau bentuk apapun;

b. pendistribusian atas Fonogram asli atau salinannya;

c. penyewaan kepada publik atas salinan Fonogram; dan

d. penyediaan atas Fonogram dengan atau tanpa kabel yang dapat diakses publik.

(3) Pendistribusian sebagaimana dimaksud pada ayat (2) huruf b, tidak berlaku terhadap salinan Fiksasi atas pertunjukan yang telah dijual atau yang telah dialihkan kepemilikannya oleh Produser Fonogram kepada pihak lain.

(4) Setiap Orang yang melaksanakan hak ekonomi Produser Fonogram sebagaimana dimaksud pada ayat (2) wajib mendapatkan izin dari Produser Fonogram.

Berdasarkan Pasal 24 UU No. 28 Tahun 2014, maka produser fonogram sebagai subjek pemegang hak terkait diberikan perlindungan oleh undang-undang untuk memiliki hak ekonomi dalam hal ini mechanical rights meliputi hak melaksanakan sendiri, memberikan izin, atau melarang pihak lain untuk melakukan penggandaan atas Fonogram dengan cara atau bentuk apapun, pendistribusian atas Fonogram asli atau salinannya, penyewaan kepada publik atas

\footnotetext{
20 Harjono, Konstitusi Sebagai Rumah Bangsa (Sekretariat Jenderal dan Kepaniteraan Mahkamah Konstitusi 2008) 373.
} 
salinan Fonogram, dan penyediaan atas Fonogram dengan atau tanpa kabel yang dapat diakses publik. Masa berlaku perlindungan ekonomi bagi Produser Fonogram, berlaku selama 50 (lima puluh) tahun sejak Fonogramnya difiksasi (vide Pasal 63 ayat (1) huruf b UU No. 28 Tahun 2014).

\section{Pencatatan Produk Hak Terkait dan Pengalihan Hak Atas Pencatatan}

Pasal 66 ayat (1) UU No. 28 Tahun 2014 menyatakan: "Pencatatan Ciptaan dan produk Hak Terkait diajukan dengan Permohonan secara tertulis dalam bahasa Indonesia oleh Pencipta, Pemegang Hak Cipta, pemilik Hak Terkait, atau Kuasanya kepada Menteri." Dalam hal permohonan pencatatan Ciptaan dan produk Hak Terkait diajukan oleh: a) beberapa orang yang secara bersama-sama berhak atas suatu Ciptaan atau produk Hak Terkait, permohonan dilampiri keterangan tertulis yang membuktikan hak tersebut; atau b) badan hukum, permohonan dilampiri salinan resmi akta pendirian badan hukum yang telah disahkan oleh pejabat berwenang (vide Pasal 67 ayat (1) UU No. 28 Tahun 2014).

Pengalihan Hak atas pencatatan produk Hak Terkait dapat dilakukan jika seluruh Hak Cipta atas Ciptaan tercatat dialihkan haknya kepada penerima hak. Pengalihan Hak dilakukan dengan mengajukan permohonan tertulis dari kedua belah pihak atau dari penerima hak kepada Menteri (vide Pasal 76 ayat (1) dan ayat (2) UU No. 28 Tahun 2014).

Berdasarkan hal tersebut, maka melalui pencatatan produk Hak Terkait dan pengaturan pengalihan Hak atas pencatatan produk Hak Terkait, produser fonogram mendapatkan jaminan perlindungan hukum terhadap mechanical rights yang dimilikinya dari pengkomersilan secara illegal oleh pihak lain.

\section{Larangan Terhadap Pihak Lain}

Jaminan perlindungan hukum terhadap hak terkait produser fonogram atas mechanical rights fonogram juga diberikan melalui larangan terhadap pihak lain dalam UU No. 28 Tahun 2014, yaitu:

a) Pengelola tempat perdagangan dilarang membiarkan penjualan dan/atau penggandaan barang hasil pelanggaran Hak Cipta dan/atau Hak Terkait di tempat perdagangan yang dikelolanya (vide Pasal 10 UU No. 28 Tahun 2014).

b) Setiap Orang dilarang merusak, $\mathrm{m}$ e $\mathrm{m} \mathrm{u} \mathrm{s} \mathrm{n} \mathrm{h} \mathrm{k} \mathrm{a}$, menghilangkan, atau membuat tidak berfungsi sarana kontrol teknologi yang digunakan sebagai pelindung Ciptaan atau produk Hak Terkait serta pengaman Hak Cipta atau Hak Terkait, kecuali untuk kepentingan pertahanan dan 
keamanan negara, serta sebab lain sesuai dengan ketentuan peraturan perundangundangan, atau diperjanjikan lain (vide Pasal 52 UU No. 28 Tahun 2014).

\section{Pemberian Imbalan yang Wajar, Lisensi dan Royalti}

UU No. 28 Tahun 2014 memberikan jaminan perlindungan hukum terhadap hak terkait produser fonogram atas mechanical rights fonogram melalui pemberian imbalan yang wajar, lisensi dan royalti terhadap produk Hak Terkait. Pemberian imbalan yang wajar diatur dalam Pasal 27 UU No. 28 Tahun 2014 yang menyatakan:

(1) Fonogram yang tersedia untuk diakses publik dengan atau tanpa kabel harus dianggap sebagai Fonogram yang telah dilakukan Pengumuman untuk kepentingan komersial.

(2) Pengguna harus membayar imbalan yang wajar kepada Produser Fonogram jika Fonogram telah dilakukan Pengumuman secara komersial atau Penggandaan Fonogram tersebut digunakan secara langsung untuk keperluan Penyiaran dan/atau Komunikasi.

(3) Hak untuk menerima imbalan yang wajar sebagaimana dimaksud pada ayat (2) berlaku selama 50 (lima puluh) tahun sejak tanggal Pengumuman.

Selain itu, pihak lain yang ingin merekam, memperbanyak, serta mengedarkan sebuah karya cipta bagi kepentingan komersial berkewajiban mendapatkan lisensi mekanikal. ${ }^{21}$ Lisensi adalah izin tertulis yang diberikan oleh Pemegang Hak Cipta atau Pemilik Hak Terkait kepada pihak lain untuk melaksanakan hak ekonomi atas Ciptaannya atau produk Hak Terkait dengan syarat tertentu (vide Pasal 1 angka 20 UU No. 28 Tahun 2014). Kecuali diperjanjikan lain, pemegang Hak Cipta atau pemilik Hak Terkait berhak memberikan Lisensi kepada pihak lain berdasarkan perjanjian tertulis untuk melaksanakan perbuatan sebagaimana dimaksud dalam Pasal 24 ayat (2) (vide Pasal 80 UU No. 28 Tahun 2014). Perjanjian Lisensi harus dicatatkan oleh Menteri dalam daftar umum perjanjian Lisensi Hak Cipta dengan dikenai biaya (vide Pasal 83 ayat (1) UU No. 28 Tahun 2014).

Pada karya musik dan lagu, perjanjian lisensi ini berkaitan dengan hak ekonomi yang dimiliki pemilik atau pemegang hak cipta (pemberi kuasa) lagu untuk mendapatkan keuntungan ekonomi secara maksimal atas hasil ciptaan mereka. ${ }^{22}$ Lisensi tersebut bukan diberikan dengan cuma-cuma, sebagai imbalan dari izin tersebut,

$21 \quad$ Husain Audah, Loc.cit.

22 Tommy Hottua Marbun, T. Keizeirina Devi Azwar, dan Windha, 'Perlindungan Hukum Hak Cipta Terhadap Karya Cipta Lagu Dan Musik Dalam Bentuk Ringtone Pada Telepon Seluler' 2013) 1 Transparency Jurnal Hukum Ekonomi 1, 3. 
Produser Fonogram yang memberikan izin memperoleh pembayaran yang disebut dengan royalti. ${ }^{23}$ Royalti adalah imbalan atas pemanfaatan Hak Ekonomi suatu Ciptaan atau Produk Hak Terkait yang diterima oleh pencipta atau pemilik hak terkait (vide Pasal 1 angka 21 UU No. 28 Tahun 2014). Penentuan besaran Royalti dan tata cara pemberian Royalti dilakukan berdasarkan perjanjian Lisensi antara Pemegang Hak Cipta atau pemilik Hak Terkait dan penerima Lisensi (vide Pasal 80 ayat (4) UU No. 28 Tahun 2014). Besaran Royalti dalam perjanjian Lisensi harus ditetapkan berdasarkan kelaziman praktik yang berlaku dan memenuhi unsur keadilan (vide Pasal 80 ayat (5) UU No 28 Tahun 2014).

\section{Lembaga Manajemen Kolektif}

Lembaga Manajemen Kolektif adalah institusi yang berbentuk badan hukum nirlaba yang diberi kuasa oleh Pencipta, Pemegang Hak Cipta, dan/atau pemilik Hak Terkait guna mengelola hak ekonominya dalam bentuk menghimpun dan mendistribusikan royalti (vide Pasal 80 ayat (4) UU No. 28 Tahun 2014). Berdasarkan hal tersebut, maka para Produser Fonogram tak perlu repot-repot menjaga karya mereka, karena akan ada lembaga yang membantu mengumpulkan royalti dari penggunaan atas mechanical rights secara komersial oleh pihak lain.
Pihak lain yang hendak memanfaatkan mechanical rights atas fonogram dapat membuat perjanjian dengan Lembaga Manajemen Kolektif yang berisi kewajiban untuk membayar Royalti atas Hak Terkait yang digunakan (vide Pasal 87 ayat (3) UU No. 28 Tahun 2014). Jikalau pemanfaatan mechanical rights secara komersial oleh pihak lain sepanjang pihak lain tersebut telah melakukan dan memenuhi kewajiban sesuai perjanjian dengan Lembaga Manajemen Kolektif, maka tidak dianggap sebagai pelanggaran terhadap UU No. 28 Tahun 2014 (vide Pasal 87 ayat (4) UU No. 28 Tahun 2014).

\section{Pengalihan Hak Ekonomi}

Pasal 29 UU No. 28 Tahun 2014 menyatakan bahwa pengalihan hak ekonomi atas Ciptaan sebagaimana dimaksud dalam Pasal 16, Pasal 17, dan Pasal 19 berlaku secara mutatis mutandis terhadap pengalihan hak ekonomi atas produk Hak Terkait. Hal tersebut berarti:

a) Hak Terkait merupakan Benda bergerak tidak berwujud.

b) Hak Terkait dapat beralih atau dialihkan, baik seluruh maupun sebagian karena: pewarisan; hibah; wakaf; wasiat; perjanjian tertulis; atau sebab lain yang dibenarkan

23 Gunawan Widjaja, Lisensi Atau Waralaba (PT. Raja Grafindo Persada 2002) 4. 
sesuai dengan ketentuan peraturan perundangundangan.

c) Hak Terkait dapat dijadikan sebagai objek jaminan fidusia.

d) Hak ekonomi atas fonogram tetap berada di tangan Produser Fonogram selama Produser Fonogram tidak mengalihkan seluruh hak ekonomi dari tersebut kepada penerima pengalihan hak atas fonogram.

e) Hak ekonomi yang dialihkan Produser Fonogram untuk seluruh atau sebagian tidak dapat dialihkan untuk kedua kalinya oleh Produser Fonogram yang sama.

f) Hak Terkait yang dimiliki Produser Fonogram yang belum, telah, atau tidak dilakukan Pengumuman, Pendistribusian, atau Komunikasi setelah Produser Fonogram meninggal dunia menjadi milik ahli waris atau milik penerima wasiat.

\section{Penyelesaian Sengketa}

UU No. 28 Tahun 2014 mengatur juga penyelesaian sengketa, terkait penelitian ini jika terjadi sengketa antara produser fonogram dan pihak lain terkait mechanical rights atas fonogram. Penyelesaian sengketa Hak Cipta dapat dilakukan melalui alternatif penyelesaian sengketa, arbitrase, atau pengadilan (vide Pasal 95 ayat (1) UU No. 28 Tahun 2014). Pengadilan yang berwenang adalah Pengadilan Niaga (vide Pasal 95 ayat (2) UU No. 28 Tahun 2014).
Selain pelanggaran Hak Cipta dan/ atau Hak Terkait dalam bentuk Pembajakan, sepanjang para pihak yang bersengketa diketahui keberadaannya dan/atau berada di wilayah Negara Kesatuan Republik Indonesia harus menempuh terlebih dahulu penyelesaian sengketa melalui mediasi sebelum melakukan tuntutan pidana (vide Pasal 95 ayat (4) UU No. 28 Tahun 2014).

\section{Ganti Rugi dan Hak Gugat}

Pencipta, pemegang Hak Cipta dan/ atau pemegang Hak Terkait atau ahli warisnya yang mengalami kerugian hak ekonomi berhak memperoleh Ganti Rugi (vide Pasal 96 ayat (1) UU No. 28 Tahun 2014). Pencipta, Pemegang Hak Cipta, atau pemilik Hak Terkait berhak mengajukan gugatan ganti rugi kepada Pengadilan Niaga atas pelanggaran Hak Cipta atau produk Hak Terkait (vide Pasal 99 ayat (1) UU No. 28 Tahun 2014).

Berdasarkan hal tersebut, maka melalui ganti rugi dan hak gugat, produser fonogram mendapatkan jaminan perlindungan hukum terhadap mechanical rights yang dimilikinya dari pengkomersilan oleh pihak lain. Selain itu, UU No. 28 Tahun 2014 juga menyatakan bahwa Hak untuk mengajukan gugatan keperdataan atas pelanggaran Hak Cipta dan/atau Hak Terkait tidak mengurangi Hak Pencipta dan/atau pemilik Hak Terkait untuk menuntut secara 
pidana (vide Pasal 99 ayat (3) UU No. 28 Tahun 2014).

\section{Permohonan putusan provisi atau putusan sela kepada Pengadilan Niaga}

Perlindungan hukum terhadap Hak Terkait produser fonogram atas mechanical rights fonogram yang dikomersilkan oleh pihak lain juga diatur dalam Pasal 99 ayat (3) UU No. 28 Tahun 2014, yaitu mengenai Pemilik Hak Terkait dapat memohon putusan provisi atau putusan sela kepada Pengadilan Niaga untuk:

a. meminta penyitaan Ciptaan yang dilakukan Pengumuman atau Penggandaan, dan/atau alat Penggandaan yang digunakan untuk menghasilkan Ciptaan hasil pelanggaran produk Hak Terkait; dan/atau

b. menghentikan kegiatan Pengumuman, Pendistribusian, Komunikasi, dan/atau Penggandaan Ciptaan yang merupakan hasil pelanggaran produk Hak Terkait.

Berdasarkan Pasal 99 ayat (3) UU No. 28 Tahun 2014, maka pemilik Hak Terkait, dalam hal ini produser fonogram sebagai subjek pemegang mechanical rights atas fonogram dapat memohon putusan provisi atau putusan sela kepada Pengadilan Niaga untuk meminta penyitaan alat penggandaan dan menghentikan kegiatan usaha pihak lain yang telah melakukan pelanggaran terhadap mechanical rights milik produser fonogram.
10. Perlindungan Melalui Ketentuan Pidana

Terkait dengan hak ekonomi produser fonogram sehubungan dengan mechanical rights atas fonogram yang dikomersialkan oleh pihak lain, ketentuan pidananya diatur dalam Pasal 114 dan Pasal 117 UU No. 28 Tahun 2014, yaitu:

a) Sanksi terhadap Pengelola Perdagangan;

Setiap Orang yang mengelola tempat perdagangan dalam segala bentuknya yang dengan sengaja dan mengetahui membiarkan penjualan dan/atau penggandaan barang hasil pelanggaran Hak Cipta dan/atau Hak Terkait di tempat perdagangan yang dikelolanya sebagaimana dimaksud dalam Pasal 10, dipidana dengan pidana denda paling banyak Rp100.000.000,00 (seratus juta rupiah) (vide Pasal 114 UU No. 28 Tahun 2014).

b) Sanksi terhadap penggandaan atas Fonogram dengan cara atau bentuk apapun;

Setiap Orang yang dengan sengaja dan tanpa hak melakukan pelanggaran hak ekonomi sebagaimana dimaksud dalam Pasal 24 ayat (2) huruf c untuk Penggunaan Secara Komersial dipidana dengan pidana penjara paling lama 1 (satu) tahun dan/atau pidana denda paling banyak $\mathrm{Rp}$ 100.000.000 (seratus juta rupiah) 
(vide Pasal 117 ayat (1) UU No. 28 Tahun 2014).

c) Sanksi terhadap pendistribusian atas Fonogram asli atau salinannya; penyewaan kepada publik atas salinan Fonogram; dan penyediaan atas Fonogram dengan atau tanpa kabel yang dapat diakses publik

Setiap Orang yang dengan sengaja dan tanpa hak melakukan pelanggaran hak ekonomi sebagaimana dimaksud dalam Pasal 24 ayat (2) huruf a, huruf $b$, dan/atau huruf d untuk Penggunaan Secara Komersial, dipidana dengan pidana penjara paling lama 4 (empat) tahun dan/ atau pidana denda paling banyak Rp 1.000.000.000,00 (satu miliar rupiah) (vide Pasal 117 ayat (2) UU No. 28 Tahun 2014). Setiap Orang yang memenuhi unsur sebagaimana dimaksud pada ayat (2) yang dilakukan dalam bentuk Pembajakan dipidana dengan pidana penjara paling lama 10 (sepuluh) tahun dan/atau pidana denda paling banyak $\mathrm{Rp}$ 4.000.000.000,00 (empat miliar rupiah) (vide Pasal 117 ayat (3) UU No. 28 Tahun 2014).

Setiap ketentuan UU No. 28 Tahun 2014 dalam upaya perlindungan terhadap hak terkait produser fonogram atas mechanical rights fonogram yang dikomersilkan oleh pihak lain membutuhkan dukungan pemerintah dan masyarakat sehingga tercipta upaya yang komprehensif, sistematis, dan berkelanjutan. Pelaksanaan edukasi hukum UU No. 28 Tahun 2014 terhadap penarikan royalti hak terkait produser fonogram atas mechanical rights fonogram yang dikomersilkan oleh pihak lain harus berada dalam pengawasan pemerintah. Sementara itu, pemerintah melalui aparatur hukum juga harus menjadi ujung tombak proses penegakan hukum terhadap setiap pihak lain yang memanfaatkan mechanical rights atas fonogram milik produser fonogram secara ilegal.

\section{KESIMPULAN}

Mechanical right atas fonogram berkenaan dengan penggandaan atau reproduksi suatu fonogram. Berdasarkan Pasal 1 angka 12 UU No. 28 Tahun 2014: "penggandaan adalah proses, perbuatan, atau cara menggandakan satu salinan Ciptaan dan/atau fonogram atau lebih dengan cara dan dalam bentuk apapun, secara permanen atau sementara”. Mechanical rights atas fonogram identik dengan "Neighboring Rights" atau "Hak Terkait" yang merupakan hak eksklusif produser fonogram yang diatur dalam Pasal 24 UU No. 28 Tahun 2014 tentang Hak Cipta.

Perlindungan hukum terhadap hak terkait produser fonogram atas mechanical rights fonogram yang dikomersilkan oleh pihak lain dalam tataran hukum internasional telah dijamin oleh Rome Convention for the Protection of Performers, Producers of Phonograms and Broadcasting Organizations 1961 dan WIPO Performances and Phonograms Treaty 1996 yang telah diratifikasi melalui Keputusan Presiden Republik Indonesia 
Nomor 74 Tahun 2004 Tentang Pengesahan Wipo Performances And Phonograms Treaty 1996. Sedangkan dalam tataran hukum nasional telah dijamin oleh UU No. 28 Tahun 2014.

Adanya UU No. 28 Tahun 2014 ini sebenarnya sudah cukup baik dalam memberikan perlindungan kepada produser fonogram atas mechanical rights fonogram yang dikomersilkan oleh pihak lain dibandingkan dengan Undang-Undang Hak Cipta yang lama. Hal ini karena dalam UU No. 28 Tahun 2014 telah diatur mengenai Lembaga Manajemen Kolektif. Oleh sebab itu diharapkan dalam menjalankan tugas dan wewenangnya LMKN bekerja dengan sungguh-sungguh dalam rangka memberikan perlindungan kepada produser fonogram atas royalti mechanical rights fonogram yang dikomersilkan oleh pihak lain. Sejauh ini belum ada peraturan pelaksanaan (Peraturan Pemerintah) dari UU No. 28 Tahun 2014, sehingga UU tersebut belum dapat diterapkan dengan maksimal. Oleh sebab itu Pemerintah agar mempercepat penyusunan Peraturan Pemerintah guna menunjang penerapan UU No. 28 Tahun 2014.

\section{DAFTAR PUSTAKA}

\section{Buku:}

ASCAP, A Bill of Rights For Songwriters And Composers, (Music Copyright in the Digital Age: A Position Paper, Maret 2008).

Audah, Husain, Hak Cipta \& Karya Cipta Musik (Pustaka Litera Antar Nusa 2004).

Damian, Eddy, Hukum Hak Cipta Menurut Beberapa Konvensi Internasional, Undang-Undang Hak Cipta 1997 dan Perlindungan Terhadap Buku serta Perjanjian Penerbitannya (Citra Aditya Bakti 1997).

Ficsor, Mihaly, Collective Management of Copyright And Related Rights (Geneva: World Intellectual Property Organization - WIPO 2002).

Harjono, Konstitusi Sebagai Rumah Bangsa (Sekretariat Jenderal dan Kepaniteraan Mahkamah Konstitusi 2008).

Marzuki, Peter Mahmud, Penelitian Hukum, cetakan keenam, (Kencana Prenada Media Group 2010).

Panjaitan, Hulman dan Wetmen Sinaga, Performing Right Hak Cipta atas Karya Musik dan Lagu Serta Aspek Hukumnya (Ind Hill Co. 2011).

Putranto, Wendi, Manual Cerdas Menguasai Bisnis Musik (Bentang Pustaka 2009). 
Widjaja, Gunawan, Lisensi Atau Waralaba (Raja Grafindo Persada, 2002).

\section{Jurnal:}

Maramis, Rezky Lendi, 'Perlindungan Hukum Hak Cipta Atas Karya Musik Dan Lagu Dalam Hubungan Dengan Pembayaran Royalti', (2014) 2 Jurnal Lex Privatum 116.

Marbun, Tommy Hottua, T. Keizeirina Devi Azwar, dan Windha, 'Perlindungan Hukum Hak Cipta Terhadap Karya Cipta Lagu Dan Musik Dalam Bentuk Ringtone Pada Telepon Seluler' (2013) 1 Transparency Jurnal Hukum Ekonomi 1, 3.

\section{Internet:}

Anonim, 'Lantaran Memperjualbelikan Lagu Tanpa Izin', (Selasa, 03 Juni 2008), $<\underline{\text { http: } / /}$ www.hukumonline.com/berita/ baca/hol19397/lantaranmemperjualbelikan-lagu-tanpaizin>, diakses 12 April 2015.

Anonim, 'Nagaswara Bakal Somasi 13 Rumah Karaoke Soal Hak Cipta', (03 september 2014), <http:// hot.detik.com/music/read/2014/ 09/03/161025/2680323/228/>, diakses 12 April 2015.

Setiawati, Lucky, 'Hak Cipta Dalam Industri Musik', <http:// www.hukumonline.com/klinik/ detail/1t506ec90e47d25/apakahmenyanyikan-ulang-lagu-oranglain-melanggar-hak-cipta>, diakses 10 April 2015. 